\title{
A Mini Review on Diagnostic Criteria of Metabolic Syndrome Associated with Chronic Obesity in Children and Adolescent
}

\author{
Shamim Shaikh Mohiuddin* \\ Department of Biochemistry, Imam Abdulrahman Bin Faisal University, Kingdom of Saudi Arabia
}

Submission: January 01, 2019; Published: January 10, 2019

*Corresponding author: Shamim Shaikh Mohiuddin, Department of Biochemistry, College of Medicine, Imam Abdulrahman Bin Faisal University, PO box- 2114, Dammam- 31541, Kingdom of Saudi Arabia

\begin{abstract}
Obesity is defined as an abnormal metabolic condition due to imbalance between amount of energy getting from food consumption and energy required for daily activity. When energy getting exceed than energy needed, ultimately person lands into obesity. Metabolic syndrome considered as a coexistence clinical sign and syndrome like hypertension, cardiovascular diseases or type 2 diabetes which used to corelate with long term obesity. Metabolic syndrome usually associated of increased circumference of waist, enhanced fasting blood glucose, hyperinsulinemia, reduced blood level of HDL cholesterol, increased peripheral arterial pressure, proinflammatory and prothrombotic states. The etiological factors of metabolic syndrome used to relate usually with two causes: "associated with adipose tissue" and "associated with diabetes". The fundamental effects of all these metabolic changes leads to increased fat mass, which is considered as basic element of the pathogenesis of insulin resistance. Inadequate physical activity, caloric and highly processed fast foods are also responsible for the development of Metabolic Syndrome. In this current review study, it was discussed how adipose tissue has an influence in the progression of metabolic syndrome and the common denominator that links obesity to insulin resistance, which leads to low grade chronic inflammatory states in children and adolescent.
\end{abstract}

Keywords: Obesity; Metabolic syndrome; Inflammation; Food consumption; Energy; Chronic inflammatory; Insulin resistance; Fasting blood glucose; Hyperinsulinemia

Abbreviations: MS: Metabolic Syndrome; FFA: Free Fatty Acids; IR: Insulin Resistance; CVD: Cardiovascular Disease; BMI: Body Mass Index; WHO: World Health Organization; ATP III: Adult Treatment Panel III; IDF: International Federation of Diabetes; WC: Waist Circumference

\section{Introduction}

Obesity is one of the leading causes of morbidity as well as mortality globally, particularly in the developed as well as developing countries. Almost one third of the American population is considered obese, with approximately 5\% considered morbidly obese [1,2]. About some decades ago, obesity was not eventually considered as a serious medical issue, but the incidence as well as prevalence of obesity has increased dramatically in the past 20 years. One of the alarming conditions is to increase the prevalence of obesity and metabolic syndrome in case of children and adolescents. This is a dangerous trend among this age groups for their future fates [3].

It's a vicious cycle that evolved childhood obesity, metabolic syndrome and type 2 diabetes with gradual development of low grade chronic inflammatory conditions. Such alarming conditions increasing without evidence to support biological evolutions in society such as changed happened due to genetic or metabolic influences. Chronic obesity is one of the well-established precipitating factors for diabetes, cardiovascular disease (CVD), hypertension, stroke, cancer, osteoarthritis, asthma, and sleep apnea. In consideration of serious health consequence of obesity and its drawback, best attention should be emphasized to the prevention, identification of pre-obese individual followed by proper treatment should be implicated [4]. This review study mainly highlighted the relationship between obesity and metabolic syndrome, the clinical implication of obesity and contemporary approach for prevention and treatment in case of children and adolescent population

\section{Definition, Overviews and Historical Background of Metabolic Syndrome (MS)}

Since $19^{\text {th }}$ Century MS had been observed and called on by several names down through the years. The first definite observations related to this syndrome occurred in the 1920 s. In 1923, Swedish doctor Eskil Kylin observed in hypertensive individuals there are association between hyperglycemia, obesity and the uric acid in the joints, known as gout, [5]. In 1965, Avogaro et al. [6] described the metabolic viewpoints related 


\section{Current Research in Diabetes \& Obesity Journal}

to obesity and mentioned a syndrome called plurimetabolic. Anyhow since 1979 there was greater improvement regarding understanding viewpoint of important component of MS, which is mainly related to Insulin Resistance (IR) [7,8]. In 1980 Reaven introduced the name of Syndrome $\mathrm{X}$ with is almost equivalent to MS, and since then the study done by Reaven [9]\& Hoffman [10] was shown the involvement of IR and hyperinsulinemia in hypertension.

Reaven [11] also discussed the relationship between the concentration of Free Fatty Acids (FFA) and status of IR and concluded into a hypothesis that IR was a central mechanism in commencement of MS. At the end, in a classic article published in 1988, Reaven \& Chan [12] proposed that a diversity of risk factors which are connected by a common pathway could the syndrome which was then called as MS. After clarification of the proper boundaries which characterize MS, he went on to define it as 'a collection of risk factors of metabolic origin that appears to be directly related to the development of atherosclerosis and cardiovascular disease [13-15]. Among these risk factors are unfavorable lipid profile, hypertension, elevated plasmatic glucose, pro-thrombotic states, proinflammatory and abdominal obesity [16,17]. So Metabolic syndrome (MS) is basically characterized by a cluster of factors which are basically metabolic in origin, such as obesity, hypertension, hypertriglyceridemia, low HDL-cholesterol and metabolism disarrangement associated with glucose metabolism, which eventually leads to cardiovascular diseases and type 2 diabetes mellitus [18]. Excessive accumulation of body fat causes resistance to insulin which acts as triggering factor for the metabolic disorders that ultimately leads to MS [19]. Recent data published in 2006 by World Health Organization (WHO) among children shows growing prevalence of overweight all over the globe. It is estimated that around 22 million people over the age of 5 are overweight [20].

Though as a diagnostic point of view, in adult population MS are well established, but its application to children and adolescents is still a subject of discussion and evaluation [21]. Till date there are no international consensus on diagnostic criteria, on cutoff limits for the variables used or on the reference curves against which to define them. Standardization of all these parameters is a real tedious task because of changes of various hormonal pattern that take place during growing phase and development and which have a metabolic effect on serum lipids and distribution of body fat [22]. Prevalence studies undertaken in children have adopted the criteria used in the two most important definitions for adults: The National Cholesterol Education Program / Third Report of the Expert Panel on Detection, Evaluation, and Treatment of High Blood Cholesterol in Adults (NCEP/ATPIII) [21] and the definition set up by WHO [21].

The different criteria depend on differing prevalence rates. According to study adopted by Cook, et al. [18] \& Ferranti et al, [20] shown prevalence rates of $4.2 \%$ and $9.2 \%$ for the same sample of adolescents in united states. Weiss et al. [21] shown that approximately $50 \%$ of severely obese patients had sign and symptoms related to MS. The evaluation done by Brazilian [23] mainly based on the ATPIII criteria, reported prevalence rates varying from $17.3 \%$ to $26.1 \%$ in obese children and adolescents. According a proposal by International Diabetes Federation (IDF) published in 2007 which based on the principle prevalence studies that had been carried out. After extensive studied they came to a conclusion that waist circumference (WC) should be consider as the most important criterion and MS can only be diagnosed after six years of age.

But between 10 and 16 years of age diagnosis should also include any two of the following criteria: low HDL-cholesterol, hypertriglyceridemia, fasting hyperglycemia or arterial hypertension [24]. Despite the different criteria proposed and the lack of any definite definition for this population, there is still enough evidence of the presence of risk factors for MS during childhood and adolescence [25].

\section{Definition and Classification of Obesity}

There are two types of fat are present in human being: brown and white. The triglycerides present in brown adipose tissue are burnt on-site and are not intended for export and they are also very highly vascularized tissue. White adipose tissue is highly metabolically active. Mature adipocytes stimulate adipoblasts (stem cells to adipocytes) to be converted by the new preadipocyte adipocytes after reaching a critical value, which is approx. $0.8 \mathrm{mg}$. Obese people have an almost unlimited ability to increase the number of adipocytes [26]. Depending on fat accumulation, obesity can be divided into gynocidal (breech-femoral) and visceral (abdominal), which is typical for the deposition of fat in the abdominal cavity. Differentiation of the arrangement number and size of adipocytes associated with the area of the body seems to be clearly marked by gender differences. In women adipocytes in the buttocks are, on average, 20 percent higher than in men, and fat around the thighs of women exhibits a nearly 90 percent greater number of adipocytes per unit volume than in men [26]. Interesting are the differences between subcutaneous fat and visceral one.

The first releases its products to the general bloodstream and there are higher levels of leptin and adiponectin than visceral tissue and lower concentrations of IL - 6 and -1 PAL and glucocorticoid receptors and androgen. Hormones secreted by abdominal adipose tissue are secreted into the portal vein directly to the liver, affecting its activity [27]. The most commonly used indicator of population studies to identify and assess the degree of obesity is body mass index BMI (body mass index, Quetelet index). It is calculated by dividing body weight ( $\mathrm{kg}$ ) by height squared. According to the World Health Organization (WHO), obesity in adults is recognized as the value of $\mathrm{BMI} \geq 30,0 \mathrm{~kg} / \mathrm{m} 2$.

Quetelet index divides obesity into classes but does not answer how fat is distributed, particularly the visceral fat. To evaluate it a simple anthropometric measurement was 


\section{Current Research in Diabetes \& Obesity Journal}

introduced: WHR (waist to hip ratio) or the ratio of waist circumference (narrowest place in it) to hip circumference (at its widest point). WHR is a measure of simple central obesity or an excessive accumulation of fat in the abdominal region [1]. Abdominal obesity is defined, if the value of WHR exceeds 0.85 in women and $1 \mathrm{in} \mathrm{men,} \mathrm{or} \mathrm{waist} \mathrm{circumference} \mathrm{(WC)} \mathrm{in} \mathrm{women}$ is $>88 \mathrm{~cm}$, and $>102 \mathrm{~cm}$ in men.

The risk of metabolic complications increases with a waist circumference [10] However, this measurement becomes useless when BMI $\geq 35 \mathrm{~kg} / \mathrm{m}^{2}$. This applies to both sexes as the risk associated with the degree of obesity becomes sufficiently high. In the NHANES III study, it was recommended that waist circumference is a better indicator of cardiovascular risk than BMI. Therefore, the rate of waist obesity was adopted and incorporated into the guidelines for the diagnosis of metabolic syndrome (both in the Adult Treatment Panel III (ATP III) and International Federation of Diabetes (IDF) [28].

\section{Epidemiology of Metabolic Syndrome}

There is drastically increased prevalence of MS in the last couple of years, transforming it into an incidence of global proportions, as like as the obesity proportions [29]. This suspicion used to confirm in a study which denotes that approximately $60 \%$ of world population with moderate obese (BMI of approximately $35 \mathrm{~kg} / \mathrm{m}^{2}$ ) clinically presented as MS, although less than $6 \%$ adults within normal weight range fulfill the criteria for the metabolic syndrome, which indicates that normal-weight population may also include into group of MS [30]. There are enough evidences that indicate 20 to $30 \%$ of the adult population can be diagnosed with MS [29].

In the United States, the prevalence of overweight children and adolescents is $6.8 \%$ and obesity is $28.7 \%$. Since different health organizations develop different criteria to diagnose MS, not counting other factors which can influence its rise, such as ethnicity and age, so the prevalence of MS varies depending on the diagnostic criteria used, [31].

According to a study done by DECODE (Diabetes Epidemiology: Collaborative Analysis of Diagnostic Criteria in Europe) there is a significant increase in death by all causes and cardiovascular complications in individuals with MS [32]. Studies done by the British, Scandinavian, and American population also almost presented the similar data [33-36].

\section{Measurement tools for Obesity Detection}

Body mass index (BMI) measurement is the most popularly used method for detection of degree of obesity and quantify health risk. BMI can be calculated based according to the formula which is based on weight of the body in $\mathrm{kg}$ and height in meter square (Table 1).

\section{BMI = Body weight $(\mathrm{kg}) /$ Height $\left(\mathrm{m}^{2}\right)$}

BMI used to consider a very good measuring tool which used to show a good correlation with total body fat and is relatively unaffected by height. Overweight usually defined as BMI of at least $25 \mathrm{~kg} / \mathrm{m}^{2}$ and obesity over $30 \mathrm{~kg} / \mathrm{m}^{2}$

Table 1: Weight Classification by Body Mass Index [37].

\begin{tabular}{|c|c|c|}
\hline Obesity Class & $\mathbf{B M I}, \mathbf{~ k g} / \mathbf{m}^{\mathbf{2}}$ & Disease Risk \\
\hline Underweight & $<18.5$ & \\
\hline Normal & $18.5-24.9$ & Increased \\
\hline Overweight & $25.0-29.9$ & Increased \\
\hline Obesity I & $30.0-34.9$ & High \\
\hline Obesity II & $35.0-39.9$ & Very high \\
\hline Obesity III & $\geq 40$ & Extremely high \\
\hline
\end{tabular}

Body Mass Index for Children and Teens

Table 2: BMI for age percentile.

\begin{tabular}{|c|c|}
\hline \multicolumn{2}{|c|}{ BMI-for-Age Percentile } \\
\hline Less than $5 \%$ & Underweight \\
\hline $5 \%$ to less than the $85 \%$ & Healthy weight \\
\hline $85 \%$ to less than the $95 \%$ & Risk of overweight \\
\hline $95 \%$ or greater & Overweight \\
\hline
\end{tabular}

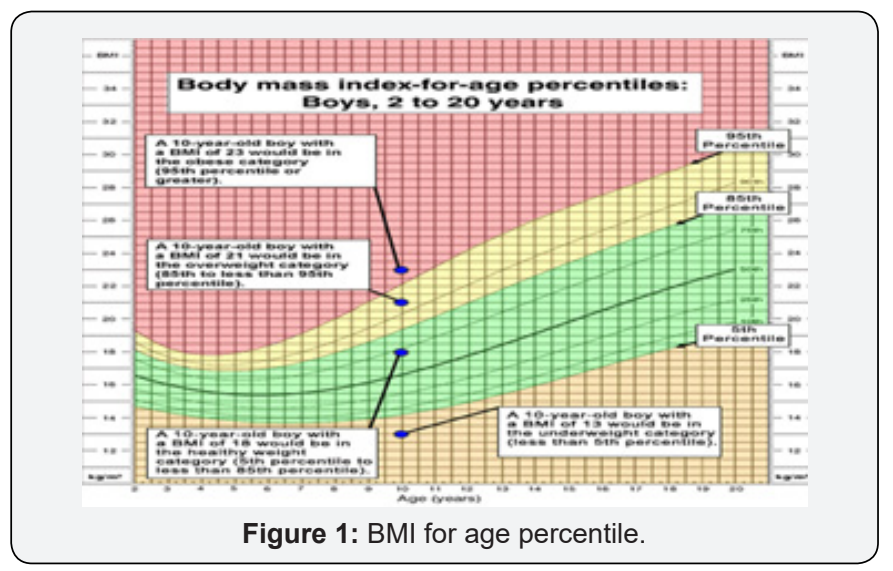

Overweight are obesity are defined differently for children and teens than for adults. Children are still growing, and boys and girls mature at different rates. BMIs for children and teens compare their heights and weights against growth charts that take age and sex into account. This is called BMI-for-age percentile (Table 2). A child or teen's BMI-for-age percentile shows how his or her BMI compares with other boys and girls of the same age (Figure I).

\section{Waist Circumference}

If individuals have abdominal obesity and most of their fat is around their waist rather than at their hips, then they are at increased risk for coronary heart disease and type 2 diabetes. The risk rises with a waist size that is greater than 35 inches for women or greater than 40 inches for men. You can also measure your waist size. To do so correctly, stand and place a tape measure around your middle, just above your hipbones. Measure your waist just after you breathe out [37].

\section{Waist-to-hip ratio}

After you determine your waist circumference, you are ready 
to check out your waist-to-hip ratio, which is a measurement that compares the size of your hips to the size of your waist. To do it correctly, use a tape measure, measure the circumference of your hips and use your waist circumference measurement, calculate your waist-to-hip ratio by dividing your waist circumference by your hip measurement. For women, ideal: less than $80 \mathrm{~cm}$, high: $80 \mathrm{~cm}$ to $88 \mathrm{~cm}$, very high: more than $88 \mathrm{~cm}$. For men, ideal: less than $94 \mathrm{~cm}$, high: $94 \mathrm{~cm}$ to $102 \mathrm{~cm}$, very high: more than $102 \mathrm{~cm}$ [37].

\section{Current Criteria for Diagnosing Metabolic Syndrome}

Risk factors which characterize MS are mainly referred to their etiology, clinical importance of the diagnosis and physio pathological mechanisms that involved in MS [38]. There are difficulties in establishing what the global prevalence of MS is mainly due to this variety of diagnostic criteria, if each criteria takes into consideration then different risk factors, different reference values and same sample evaluated by different criteria can present a wide variation in regard to prevalence [39]. In a review study done by Grundy [16] shown that the collected data regarding the prevalence of MS in populations in different regions in the world and used different criteria are showing the high prevalence of MS in the global population, and the difference in prevalence in the same populations when using different criteria.

The situation is even more complex when dealing with children and adolescents, because of the lack of consensus about the MS diagnosis in infancy that could be accepted by the whole scientific community. Different criteria currently used for the parameters related to metabolic syndrome were published in varied well-known organizations in the area of health. In 1999, the World Health Organization (WHO) published their definition of MS [6] and two years later the National Cholesterol Education Program and Adult Treatment Panel III (NCEP-ATP III) [40] in the United States also published their own criteria.

Furthermore, recent studies have shown that obese children and adolescents, with higher intra-abdominal fat are more prone to develop MS and nonalcoholic fatty liver disease than those with higher values of subcutaneous fat, independent of possible confounding variables. It may be explained by the endocrine function of the adipose tissue (adipokines production), causing inflammatory process and insulin resistance, especially visceral adipose tissue, which has particularities related to higher lipolysis and higher release of adipokines [41].

Among the cited criteria, the most used are that from WHO and that of NCEP-ATP III and some differences among them are observed. The definition from WHO requires evaluation of resistance to insulin or the alteration of the glucose metabolism. On the other hand, the definition from NCEP-ATP III does not require the measuring of resistance to insulin, facilitating its use in epidemiological studies [42].

\section{Conclusion}

The prevalence of MS has increased in the whole world's pediatric population as well as in adult population, and defining its prevalence has been an arduous task, due to the lack of consensus of its diagnostic criteria. When dealing with the ease in relation to its applicability and sensitivity, the criteria from the International Diabetes Federation can be considered the most advantageous. However, the criteria from the World Health Organization for taking into consideration the risk factors like fasting glucose, hyperinsulinemia and glucose intolerance which are mainly considering the efficacy of the diagnosis, the criteria which most emphasizes the characteristics of glycemic homeostasis, and consequently the main risk factor of MS due to resistance to insulin.

\section{Funding}

This research did not receive any specific grant from funding agencies in the public, commercial, or not-for-profit sectors.

\section{Conflict of Interest}

None

\section{References}

1. Hedley AA, Ogden CL, Johnson CL, Carroll MD, Curtin LR, et al. (2004) Prevalence of overweight and obesity among US children, adolescents and adults, 1999-2002. JAMA 291(23): 2847-2850.

2. Mokdad AH, Serdula MK, Dietz WH, Bowman BA, Marks JS, et al. (1999) The spread of the obesity epidemic in the United states, 1991-1998. JAMA 282(16): 1519-1522.

3. Flegal KM, Carroll MD, Ogden CL, Johnson CL (2002) Prevalence and trends in obesity among US adults, 1999-2000. JAMA 283(14): 17231727.

4. Stein CJ, Colditz GA (2004) The epidemic of obesity. J Clin Endocrinol Metab 89(6): 2522-2525.

5. Nilsson S (2001) Research contributions of Eskil Kylin. Sven Med Tidskr 5(1): 15-28.

6. Avogaro P, Crepaldi G, Enzi G, Tiengo A (1965) Metabolic aspects of essential obesity. Epatologia 11(3): 226-238.

7. Defronzo RA (1979) Glucose intolerance and aging: evidence for tissue insensitivity to insulin. Diabetes 28(12): 1095-1101.

8. DeFronzo RA, Tobin JD, Andres R (1979) Glucose clamp technique: a method for quantifying insulin secretion and resistance. Am J Physiol 237(3): E214-223.

9. Reaven GM, Hoffman BB (1987) A role for insulin in a etiology and course of hypertension? Lancet 2(8556): 435-437.

10. Lottenberg SA, Glezer A, Turatti LA (2007) Metabolic syndrome: identifying the risk factors. J Pediatr (Rio J) 83(5): S204-208.

11. Reaven GM (1993) Role of insulin resistance in human disease (syndrome X): an expanded definition. Annu Rev Med 44:121-131.

12. Reaven GM, Chen YD (1988) Role of abnormal free fatty acid metabolism in the development of non-insulin-dependent diabetes mellitus. Am J Med 85(5): 106-112.

13. Chen W, Srinivasan SR, Li S, Xu J, Berenson GS (2005) Metabolic syndrome variables at low levels in childhood are beneficially 


\section{Current Research in Diabetes \& Obesity Journal}

associated with adulthood cardiovascular risk: the Bogalusa Heart Study. Diabetes Care 28(1): 126-131.

14. Franks PW, Hanson RL, Knowler WC, Moffett C, Enos G, et al. (2007) Childhood predictors of young-onset type 2 diabetes. Diabetes 56(12): 2964-2972.

15. Morrison JA, Friedman LA, Gray-McGuire C (2007) Metabolic syndrome in childhood predicts adult cardiovascular disease 25 years later: the Princeton Lipid Research Clinics Follow-up Study. Pediatrics 120(2): 340-345.

16. Grundy SM (2008) Metabolic syndrome pandemic. Arterioscler Thromb Vasc Biol 28(4): 629-636.

17. Després JP, Lemieux I (2006) Abdominal obesity and metabolic syndrome. Nature 444(7121): 881-887.

18. Cook S, Weitzman M, Auinger P, Nguyen M, Dietz WH (2003) Prevalence of a metabolic syndrome phenotype in adolescents: findings from the third National Health and Nutrition Examination Survey, 1988-1994. Arch Pediatr Adolesc Med 157(8): 821-825.

19. Grundy SM, Brewer HB Jr, Cleeman JI, Smith SC Jr, Lenfant C (2004) Definition of metabolic syndrome: report of the National Heart, Lung, and Blood Institute/American Heart Association conference on scientific issues related to definition. Arterioscler Thromb Vasc Biol 24(2): e13-18.

20. De Ferranti SD, Gauvreau K, Ludwig DS, Neufeld EJ, Newburger JW, et al. (2004) Prevalence of the metabolic syndrome in American adolescents: findings from Third National Health and Nutrition Examination Survey. Circulation 110(16): 2494-2497.

21. Weiss R, Dziura J, Burgert TS, Tamborlane WV, Taksali SE, et al. (2004) Obesity and the metabolic syndrome in children and adolescents. N Engl J Med 350(23): 2362-2374.

22. Ferreira AP, Oliveira CE, França NM. Metabolic syndrome and risk factors for cardiovascular disease in obese children: the relationship with insulin resistance (HOMA-IR). J Pediatr (Rio J) 83(1): 21-26.

23. Strufaldi MW, Silva EM, Puccini RF (2008) Metabolic syndrome among prepubertal Brazilian schoolchildren. Diab Vasc Dis Res 5: 291-297.

24. da Silva RC, Miranda WL, Chacra AR, Dib SA (2005) Metabolic syndrome and insulin resistance in normal glucose tolerant brazilian adolescents with family history of type 2 diabetes. Diabetes Care 28: 716-718.

25. Zimmet P, Alberti G, Kaufman F, Tajima N, Silink M, et al. (2007) The metabolic syndrome in children and adolescents. Lancet 369(9579): 2059-2061

26. Ford ES, Li C (2008) Defining the metabolic syndrome in children and adolescents: will the real definition please stand up? J Pediatr 152(2): 160-164.

27. Kosti RI, Panagiotakos DB (2006) The epidemic of obesity in children and adolescents in the world. Cent Eur J Public Health 14(4): 151-159.

28. Brambilla P, Lissau I, Flodmark CE, Moreno LA, Wildhalm K, et al. (2007) Metabolic risk-factor clustering estimation in children: to draw a line across pediatric metabolic syndrome. Int J Obes (Lond) 31(4) 591-600.
29. Grundy SM (2008) Metabolic syndrome pandemic. Arterioscler Thromb Vasc Biol 28(4): 629-636.

30. Park YW, Zhu S, Palaniappan L, Heshka S, Carnethon MR, et al. (2003) The metabolic syndrome: prevalence and associated risk factor findings in the US population from the Third National Health and Nutrition Examination Survey, 1988-1994. Arch Intern Med 163(4): 427-436.

31. Cameron AJ, Shaw JE, Zimmet PZ (2004) The metabolic syndrome prevalence in worldwide populations. Endocrinol Metab Clin North Am 33(2): 351-375.

32. Hu G, Qiao Q, Tuomilehto J, Balkau B, Borch-Johnsen K, et al. (2004) Prevalence of the metabolic syndrome and its relation to all-cause and cardiovascular mortality in nondiabetic European men and women. Arch Intern Med 164(10): 1066-1076.

33. Isomaa B, Almgren P, Tuomi T, Forsén B, Lahti K, et al. (2001) Cardio vascular morbidity and mortality associated with the metabolic syndrome. Diabetes Care 24(4): 683-689.

34. McNeill AM, Rosamond WD, Girman CJ, Golden SH, Schmidt MI, et al. (2005) The metabolic syndrome and 11-year risk of incident cardiovascular disease in the atherosclerosis risk in communities study. Diabetes Care 28(2): 385-390.

35. Sattar N, Gaw A, Scherbakova 0, Ford I, O’Reilly DS, et al. (2003) Metabolic syndrome with and without $\mathrm{C}$-reactive protein as a predictor of coronary heart disease and diabetes in the West of Scotland Coronary Prevention Study. Circulation 108(4): 414-419.

36. Skilton MR, Moulin P, Sérusclat A, Nony P, Bonnet F (2007) A comparison of the NCEP-ATPIII, IDF and AHA/NHLBI metabolic syndrome definitions with relation to early carotid atherosclerosis in subjects with hypercholesterolemia or at risk of CVD: evidence for sexspecific differences. Atherosclerosis 190(2): 416-422.

37. Clinical guidelines on the identification, evaluation, and treatment of overweight and obesity in adults. (1998) The evidence report. National Heart, Lung, and Blood Institute and the National Institute of Diabetes and Digestive and Kidney Diseases. 98-4083.

38. Machado UF, Schaan BD, Seraphim PM (2006) Glucose transporters in the metabolic syndrome. Arq Bras Endocrinol Metabol 50(2): 177-189.

39. Sangun Ö, Dündar B, Köşker M, Pirgon Ö, Dündar N (2011) Prevalence of metabolic syndrome in obese children and adolescents using three different criteria and evaluation of risk factors. J Clin Res Pediatr Endocrinol 3(2): 70-76.

40. Executive summary of the third report of The National Cholesterol Education Program (NCEP) expert panel on detection, evaluation, and treatment of high blood cholesterol in adults (adult treatment panel III). (2001) JAMA 285(19): 2486-2497.

41. Silveira LS, Monteiro PA, Antunes Bde M, Seraphim PM, Fernandes RA, et al. (2013) Intra-abdominal fat is related to metabolic syndrome and non-alcoholic fat liver disease in obese youth. BMC Pediatr 13: 115.

42. Moraes AC, Fulaz CS, Netto-Oliveira ER, Reichert FF (2009) Prevalence of metabolic syndrome in adolescents: a systematic review. Cad Saude Publica 25(6): 1195-1202. 
(C) This work is licensed under Creative (C) Commons Attribution 4.0 Licens

BY DOI: 10.19080/CRDOJ.2018.09.555763
Your next submission with Juniper Publishers will reach you the below assets

- Quality Editorial service

- Swift Peer Review

- Reprints availability

- E-prints Service

- Manuscript Podcast for convenient understanding

- Global attainment for your research

- Manuscript accessibility in different formats

( Pdf, E-pub, Full Text, Audio)

- Unceasing customer service

Track the below URL for one-step submission https://juniperpublishers.com/online-submission.php 